\title{
EFEKTIFITAS ANTARA TERAPI RELAKSASI OTOT PROGRESIF DAN TEKNIK RELAKSASI NAFAS DALAM TERHADAP PENURUNAN TEKANAN DARAH PADA PENDERITA HIPERTENSI DI DESA PULAU BIRANDANG WILAYAH KERJA PUSKESMAS KAMPAR TIMUR TAHUN 2017
}

\author{
Muhammad Nurman \\ Dosen FIK Universitas Pahlawan Tuanku Tambusai, Riau, Indonesia \\ muhammadnurman1977@yahoo.com
}

\begin{abstract}
ABSTRAK
Sebanyak $63 \%$ kematian di dunia disebabkan oleh penyakit tidak menular, seperti Hipertensi. Hipertensi merupakan penyakit yang berkontribusi terhadap 13,5\% dari seluruh kematian. Tujuan penelitian ini untuk mengetahui efektifitas antara relaksasi otot progresif dan tehnik relaksasi nafas dalam terhadap penurunan tekanan darah pada penderita hipertensi di Desa Pulau Birandang Wilayah Kerja Puskesmas Kampar Timur Tahun 2017. Tekanan darah merupakan tekanan yang ditimbulkan oleh darah terhadap seluruh permukaaan dinding pembuluh darah. Hipertensi adalah suatu keadaan dimana seseorang mengalami peningkatan tekanan darah di atas normal yang ditunjukkan oleh angka systolic dan diastolic. Relaksasi otot progresif adalah suatu reaksi yang dilakukan dengan cara melakukan peregangan otot dan mengistirahatkannya kembali secara bertahap dan teratur. Teknik relaksasi nafas dalam merupakan metode efektif untuk mengurangi rasa nyeri. Penelitian ini menggunakan rancangan penelitian Quasi Ekperimen Desigh dengan rancangan penelitian yang digunakan adalah Two Group Pre Test and Post Test Desigh. Populasi dalam penelitian ini adalah seluruh pasien yang berkunjung ke Puskesmas Kampar timur yang mengalami hipertensi yaitu sebanyak 131 orang. Teknik pengambilan sampel ini berdasarkan pertimbangan tempat, biaya, dan waktu, Dalam penelitian ini peneliti menetapkan 30 sampel. Analisa data secara univariat dan bivariat. Berdasarkan uji $T$ dependent di peroleh nilai $\mathrm{p}$ value $0,000<$ $\mathrm{a}=0,05)$, hal ini menunjukkan terdapatnya perbedaan yang signifikan antara terapi relaksasi otot progresif dan teknik relaksasi nafas dalam terhadap penurunan tekanan darah pada penderita hipertensi di desa pulau birandang wilayah kerja puskesmas Kampar timur tahun 2017. Rata-rata penurunan dapat dilihat pada terapi relaksasi otot progresif sistolik 19,33 $\mathrm{mmHg}$ dan diastolik 5,34 $\mathrm{mmHg}$ sedangkan penurunan tekanan darah pada responden tehnik relaksasi nafas dalam sistolik $14 \mathrm{mmHg}$ dan diastolik 8,67 $\mathrm{mmHg}$ yang berarti terapi relaksasi otot orogresif lebih efektif dalam menurunkan tekanan darah pada penderita hipertensi. Diharapkan kepada peneliti selanjutnya agar dapat menambahkan jumlah responden dan memperluas cakupan penelitian.
\end{abstract}

Daftar Bacaan : 20 Referensi (2008-2014)

Kata Kunci : Relaksasi otot progresif, Teknik relaksasi nafas dalam, Hipertensi 


\section{BAB I}

\section{PENDAHULUAN}

\section{A. Latar Belakang}

Banyak penyakit yang menjadi perhatian yang sangat penting pada sektor kesehatan masyarakat, karena memiliki predikat sebagai penyebab tingginya angka kesakitan dan kematian. Berdasarkan Global Status Report on Non-communicable Disease (WHO, 2011), sebanyak 63\% kematian di dunia disebabkan oleh penyakit tidak menular, seperti penyakit kardiovaskuler, diabetes, kanker, dan penyakit pernafasan, dan 80\%-nya terjadi di negara berpendapatan menengah ke bawah (lower-middle income).

Seiring bertambahnya usia, akan mengalami beberapa perubahan stuktural dan fungsional dalam tubuhnya. Salah satu perubahan yang terjadi yaitu pada sistem kardiovaskuler tepatnya pada aorta, dimana terjadinya penurunan elastisitas pada dinding pembuluh aorta. Hal ini menyebabkan semakin parahnya pengerasan pada pembuluh darah dan semakin tingginya tekanan darah, sehingga menyebabkan hipertensi (Kowalski, 2010).

Hipertensi adalah suatu keadaan dimana seseorang mengalami peningkatan tekanan darah di atas normal yang ditunjukkan oleh angka systolic (bagian atas) dan diastolic (bagian bawah) pada pemeriksaan tensi darah menggunakan alat pengukur tekanan darah baik yang berupa cuff air raksa (sphygmomanometer) ataupun alat digital lainnya (Ratna Dewi Pudiastuti. 2011). Penyakit darah tinggi atau hipertensi telah menjadi penyakit yang umum diderita oleh banyak masyarakat Indonesia. Penyakit pembunuh paling dahsyat yang sering menjadi momok disebagian masyarakat yang tinggal didaerah perkotaan ini telah menyebar sampai wilayah pedesaan (Noviyanti, 2015).

Hipertensi merupakan penyakit yang berkontribusi terhadap 13,5\% dari seluruh kematian (Brook, et al, 2013). Hipertensi sering kali tidak menimbulkan gejala, sehingga seringkali penderita nya tidak menyadari kondisinya sampai terjadi kerusakan organ, sehingga sering disebut sebagai silent killer. Gejala hipertensi biasanya sama, seperti sakit kepala dan nyeri leher bagian kuduk sehingga sering diabaikan (LeMone \& Burke, 2008). Salah satu penyebab yang seringkali menjadi penyebab hipertensi adalah arterosklerosis atau penebalan dinding arteri yang menyebabkan hilangnya elastisitas pembuluh darah (Kholish, 2011).

Badan penelitian kesehatan dunia WHO (World Health Organization) pada tahun 2012 menunjukkan, seluruh dunia sekitar 982 juta orang atau $26,4 \%$ penghuni bumi mengidap hipertensi dengan perbandingan $26,6 \%$ pria dan $26,1 \%$ wanita. Angka ini kemungkinan akan meningkat menjadi $29,2 \%$ di tahun 2025. Penyakit tekanan darah tinggi atau hipertensi telah membunuh 9,4 juta warga dunia setiap tahunnya (WHO, 2012). Penyakit hipertensi menjadi penyebab kematian di seluruh dunia,yaitu sekitar 13\% dari total kematian (Murti, 2011). Berdasarkan hasil riset Kesehatan Dasar (Riskesdas) 2007 menunjukkan, sebagian besar kasus hipertensi di masyarakat belum 
terdiagnosis, hal ini terlihat dari hasil pengukuran tekanan darah pada usia 18 tahun ke atas ditemukan prevalensi hipertensi di Indonesia sebesar $31,7 \%$, dimana hanya $7,2 \%$ penduduk yang sudah mengetahui memiliki hipertensi dan hanya $0,4 \%$ kasus yang minum obat hipertensi (Kemenkes RI, 2012).

Hasil Riset Kesehatan Dasar (Riskesdas) tahun 2013 menunjukkan prevalensi hipertensi berdasarkan pengukuran di Provinsi Riau sebesar 20,9\%. Jika saat ini penduduk sebesar 6.358. 636 jiwa maka terdapat 1.328 .954 jiwa yang menderita hipertensi (Pusat Data dan Informasi Kementrian Kesehatan RI, 2014).

Hipertensi yang tidak segera diatasi bisa menimbulkan gejala seperti sakit kepala, kelelahan, mual, muntah, sesak nafas, terengah-engah, gelisah, pandangan kabur dan berkunang kunang, emosional, telinga berdengung, sulit tidur, tengkuk terasa berat, nyeri kepala bagian belakang dan didada, otot lemah, terjadi pembengkakan pada kaki dan pergelangan kaki, keringat berlebihan, kulit tampak pucat dan kemerahan, denyut jantung yang kuat, cepat, dan tidak teratur, impotensi, pendarahan diurin, bahkan mimisan.

Jika hipertensi ini terjadi secara berkepanjangan, maka akan meningkatkan resiko terkena stroke, serangan jantung dan gagal ginjal kronis bahkan pada hipertensi berat dapat menyebabkan ensepalopati hipertensif, penurunan kesadaran bahkan koma (Noviyanti, 2015).

Hipertensi jika tidak dilakukan penanganan, sekitar $70 \%$ pasien hipertensi kronis akan meninggal karna jantung koroner atau gagal jantung,15 \% terkena kerusakan jaringan otak, dan $10 \%$ mengalami gagal ginjal. Sejalan dengan bertambahnya usia hampir setiap orang mengalami kenaikan tekanan darah dan akan terus meningkat sampai usia 80 tahun (Noviyanti, 2015).

Dari pengalaman klinis diketahui penggunaan obat sintesis dapat mengendalikan tekanan darah. Pengobatan secara farmakologi bila digunakan dalam jangka waktu lama biasanya mahal dan berefek samping. Hal ini menimbulkan masalah dari segi kesehatan maupun biaya. Sehingga masalah tersebut dijadikan alasan bagi masyrakat untuk menggunakan pengobatan alternatif atau pengobatan non farmakologi (Jain, 2011).

Beberapa jenis pengobatan alternative yang dapat digunakan untuk menurunkan tekanan darah adalah akupresur (akupuntur tanpa jarum), pengobatan herbal dari cina, terapi jus, pijat, yoga, aromaterapi, pernafasan dan relaksasi, biofeetback, meditasi dan hypnosis (Jain, 2011).

Relaksasi otot progresif (PMR) adalah suatu metedo utuk membantu menurunkan tegangan otot sehingga tubuh menjadi rileks. Pertama kali diperkenalkan oleh Edmund Jacobson, seorang dokter dari Amerika Serikat, pada tahun 1938. Dalam bukunya, Jacobson menjelaskan bahwa saat ketegangan otot secara signifikan menurun, maka kesempatan untuk munculnya penyakit dapat dikurangi.

Smeltzer \& Bare (2002) mengatakan tujuan relaksasi adalah untuk menghasilkan respon yang dapat mengurangi strees. Dengan demikian, saat melakukan relaksasi 
otot progresif dengan tenang, rileks dan penuh konsentrasi yang dilatih selama 30 menit maka sekresi CRH (Cotricotropin Releasing Hormone) dan ACTH (Adrenocorticotropic Hormone) di kelenjar hipotalamus menurun. Penurunan kedua sekresi hormon ini menyebabkan aktivitas syaraf simpatis menurun sehingga pengeluaran hormon adrenalin dan hormon noradrenalin berkurang, akibatnya terjadi penurunan denyut jantung, pembuluh darah melebar, tahanan pembuluh darah berkurang dan penurunan pompa jantung sehingga tekanan darah arterial jantung menurun (Sherwood, 2011).

Berdasarkan penelitian terdahulu oleh Shinde, KJ, SM dan Hande (2013) tentang "Efektifitas Relaksi Otot Progresif Terhadap Tekanan Darah Pada Penderita Hipertensi Esensial" Hasil penelitian menunjukan terdapat perbedaan yang segnifikan pada tekanan darah dan jantung pre dan post intervensi, secara stastistik didapatkan hasil pada tekanan darah sistolik $(\mathrm{p}<0,01)$. Tekanan darah diastolic $(\mathrm{p}=0,05)$ dan denyut jantung $(p<0,05)$ terjadi penurunan yang segnifikan setelah melaksanakan relaksasi otot progresif.

Teknik relaksasi nafas dalam merupakan suatu bentuk asuhan keperawatan, yang dalam hal ini perawat mengajarkan kepada klien bagaimana cara melakukan napas dalam, napas lambat (menahan inspirasi secara maksimal) dan bagaimana menghembuskan napas secara perlahan, Selain dapat menurunkan intensitas nyeri, teknik relaksasi nafas dalam juga dapat meningkatkan ventilasi paru dan meningkatkan oksigenasi darah (Smeltzer \& Bare, 2002).
Peran perawat dalam pemberian asuhan keperawatan adalah membantu penderita hipertensi untuk mempertahankan tekanan darah pada tingkat optimal dan meningkatkan kualitas kehidupan secara maksimal dengan cara member intervensi asuhan keperawatan sehingga dapat memperbaiki kondisi kesehatan. Salah satu tindakan yang dapat diberikan untuk menurunkan tekanan darah pada penderita hipertensi adalah pemberian teknik relaksasi nafas dalam mekanisme relaksasi nafas dalam pada sistem pernafasan berupa suatu keadaan inspirasi dan ekspirasi pernafasan dengan frekuensi pernafasan menjadi 6-10 kali permenit sehingga terjadi peningkatan rengang kardiopulmonari (Izzo, 2008).

Berdasarkan penelitian terdahulu yang dilakukan oleh Rini Tri Hastuti, Insiyah dengan judul "Penurunan Tekanan Darah Dengan Menggunakan Teknik Nafas Dalam (DEEP BREATHING) Pada Pasien Hipertensi Di Puskesmas Bendosari Kabupaten Sukoharjo Tahun 2015" Hasil peneitian ini menunjukkan bahwa tekanan darah pada pasien hipertensi di Puskesmas Bendosari Kabupaten Sukoharjo sebelum terapi teknik terapi nafas dalam (DEEP BREATHING) yaitu tekanan darah sistol rata-rata $177,33 \mathrm{mmhg}$ dan diastol rata-rata 95,87 mmhg. Tekanan darah pada pasien hipertensi di Puskesmas Bendosari Kabupaten Sukoharjo sesudah terapi teknik nafas dalam (DEEP BREATHING) yaitu tekanan darah sistol rata-rata 173,20 mmhg dan diastol rata-rata 90,57 mmhg. Ada pengaruh terapi teknik nafas dalam terhadap penurunan tekanan darah pada pasien 
hipertensi di Puskesmas Bendosari Kabupaten Sukoharjo.

Berdasarkan data dari Dinas Kesehatan Kabupaten Kampar Tahun 2016, hipertensi masuk kedalam sepuluh besar penyakit terbanyak di Kabupaten Kampar yaitu menempati urutan ke-2 dengan jumlah 5.993 kasus. Kasus terbanyak terjadi di Puskesmas Kampar Timur dengan jumlah pasien 656 orang. Berdasarkan survei pendahuluan yang dilakukan di Puskesmas Kampar Timur tahun 2017 dari bulan Januari-Maret yang mengalami hipertensi sebanyak 131 orang yang terdiri dari laki-laki sebanyak 42 orang sedangkan perempuan sebanyak 89 orang, pasien yang

Tabel 1.1 Jumlah Kejadian Hipertensi di Wilayah Kerja Puskesmas Kampar Timur Tahun 2016-2017

\begin{tabular}{clcccc}
\hline \multirow{2}{*}{ No } & \multirow{2}{*}{ Nama Desa } & \multicolumn{2}{c}{ Tahun 2016 } & \multicolumn{2}{c}{ Tahun 2017 } \\
\cline { 3 - 6 } & & Kasus & Persentasi & Kasus & Persentasi \\
\hline 1 & Sawah Baru & 79 & $8,68 \%$ & 15 & $11,45 \%$ \\
2 & Pulau Rambai & 83 & $9,12 \%$ & 12 & $9,16 \%$ \\
3 & Kampar & 90 & $9,89 \%$ & 9 & $6,87 \%$ \\
4 & Koto Perambahan & 86 & $9,45 \%$ & 10 & $7,63 \%$ \\
5 & Pulau Birandang & $\mathbf{2 1 5}$ & $\mathbf{2 7 , 5 8 \%}$ & $\mathbf{3 2}$ & $\mathbf{2 4 , 4 2 \%}$ \\
6 & Sungai Putih & 93 & $10,21 \%$ & 17 & $12,97 \%$ \\
7 & Deli Makmur & 100 & $10,98 \%$ & 11 & $8,39 \%$ \\
8 & Sungai Terap & 101 & $11,09 \%$ & 17 & $12,97 \%$ \\
9 & Tanjung Bungo & 63 & $6,92 \%$ & 8 & $6,10 \%$ \\
\hline & Jumlah & 910 & $100 \%$ & 131 & $100 \%$ \\
\hline
\end{tabular}

Sumber: Puskesmas Kampar Timur tahun 2016 dan bulan januari- maret tahun 2017

Berdasarkan tabel 1.1 bahwa jumlah hipertensi di Desa Pulau Birandang tahun 2016 sebanyak 215 kasus $(27,58 \%)$ dan data pada bulan Januari-Maret tahun 2017 sebanyak 32 kasus $(24,42 \%)$.

Berdasarkan fenomena di atas, maka peneliti tertarik untuk melakukan penelitian dengan judul penelitian "Efektifitas Antara Terapi Relaksasi Otot Progresif dan Tehnik Relaksasi Nafas Dalam Terhadap Penurunan Tekanan Darah Pada Penderita Hipertensi di Desa Pulau mengalami hipertensi mengatakan kepalanya merasa sakit, tekuk terasa berat, dan mata berkunang-kunang. Sebanyak 86 orang pasien mengatakan hanya meminum obatobatan dari puskesmas, dan sebanyak 45 orang mengatakan hanya istirahat saja dan diberi minyak angin atau balsam. Sedangkan untuk menggunakan terapi relaksasi otot progresif dengan tehnik relaksasi nafas dalam untuk menurunkan hipertensi belum pernah dilakukan.

Data jumlah kejadian hipertensi di Wilayah Kerja Puskesmas Kampar timur tahun 2016 dan data 2017 dari bulan Januari-Maret dapat dilihat pada tabel di bawah ini: 


\section{Tujuan Umum}

Untuk mengetahui efektifitas antara relaksasi otot progresif dan tehnik relaksasi nafas dalam terhadap penurunan tekanan darah pada penderita hipertensi di Desa Pulau Birandang Wilayah Kerja Puskesmas Kampar Timur Tahun 2017.

\section{Tujuan Khusus}

a. Mengetahui tekanan darah sebelum dilakukan terapi relaksasi otot progresif dengan tehnik relaksasi nafas dalam.

b. Mengetahui tekanan darah sesudah dilakukan terapi relaksasi otot progresif dengan tehnik relaksasi nafas dalam.

c. Mengetahui efektifitas antara terapi relaksasi otot progresif dengan tehnik relaksasi nafas dalam.

\section{Manfaat Penelitian}

Manfaat yang dapat diambil dari penelitian ini adalah untuk dapat mengetahui efektifitas relaksasi otot progresif dengan tehnik relaksasi nafas dalam terhadap penurunan tekanan darah pada penderita hipertensi. Adapun manfaat penulisan adalah sebagai berikut:

\section{Aspek Teoritis (keilmuan)}

Penelitian ini diharapkan dapat memberikan suatu masukan untuk teori dan penambahan hasil informasi ilmiah yang berhubungan dengan terapi non farmakologis untuk mengurangi tekanan darah tinggi. Hasil

1. Rancangan Penelitian Pretest

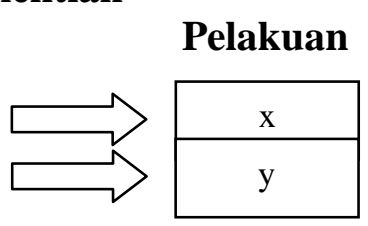

Skema 3.1 Rancangan Penelitian

\section{BAB III}

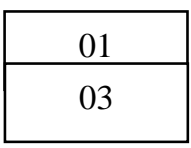

penelitian ini dapat digunakan untuk menyusun hipotesis baru dalam merancang penelitian berikutnya.

\section{Aspek Praktis (gunalaksana)}

Hasil penelitian ini diharapkan dapat digunakan sebagai media informasi dan mengembangkan ilmu keperawatan sehingga dapat mengaplikasikan tehnik relaksasi otot progresif dengan tehnik relaksasi nafas dalam.

\section{METODE PENELITIAN}

\section{A. Desain Penelitian}

Penelitian ini menggunakan rancangan penelitian Quasi Ekperimen Desigh dengan rancangan penelitian yang digunakan adalah Two Group Pre Test and Post Test Desigh. Yang artinya sampel pada penelitian ini diobservasi terlebih dahulu sebelum diberi perlakuan, kemudian setelah diberi perlakuan sampel tersebut diobservasi kembali (Hidayat, 2007). Dalam penelitian ini terdiri dari 2 kelompok intervensi yaitu kelompok intervensi I yang merupakan kelompok yang diberikan terapi relaksasi otot progresif dan kelompok intervensi II yaitu kelompok yang melakukan teknik relaksasi nafas dalam. Kedua kelompok dilakukan pretest dan posttest kemudian hasilnya dibandingkan.

\section{Posttest}

Keterangan :
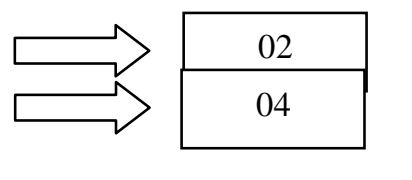
01 : Pengukuran tekanan darah sebelum diberikan perlakuan

$\mathbf{X}$ : Perlakuan yang diberikan (terapi relaksasi otot progresif)

02 : Pengukuran tekanan darah sesudah diberikan perlakuan

03 : Pengukuran tekanan darah sebelum diberikan perlakuan
Y : Perlakuan yang diberikan (Teknik relaksasi napas dalam)

04 : Pengukuran tekanan darah sesudah diberikan perlakuan

\section{Alur Penelitian}

Secara sistematis, alur penelitian dapat dilihat dalam skema 3.2

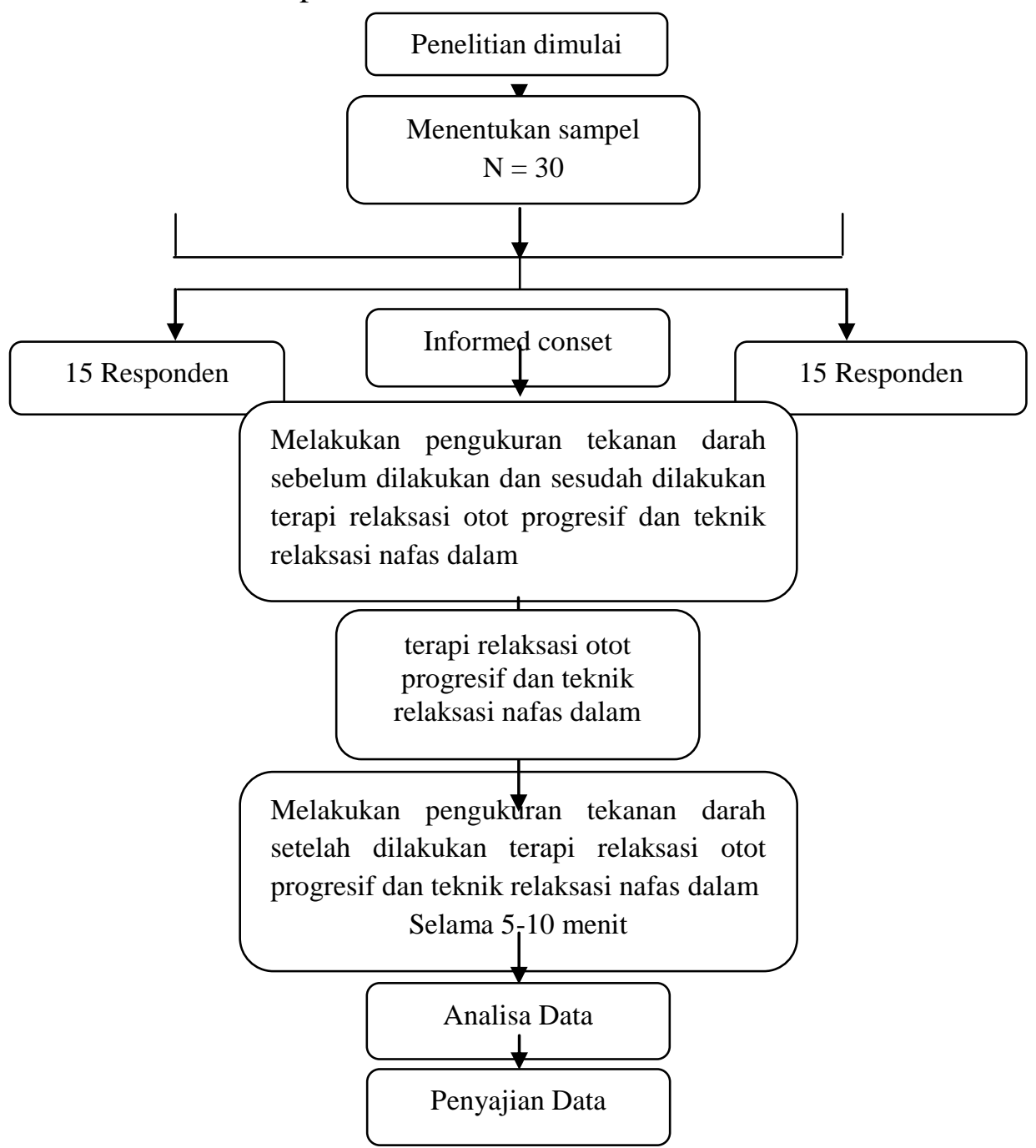

Skema 3.2 Alur Penelitian

\section{Prosedur Penelitian}

Adapun langkah-langkah dalam penelitian ini akan diuraikan sebagai berikut :

a. Mengajukan permohonan surat izin pengambilan data kepada bagian program studi S1 Keperawatan Universitas Pahlawan Tuanku Tambusai. b. Setelah surat permohonan izin pengambilan data, maka peneliti dapat langsung memperloleh data mengenai jumlah pasien hipertensi dari tempat yang akan dilakukan penelitian.

c. Meminta izin kepada Puskesmas Kampar Timur. 
d. Pada hari pertama, peneliti menerangkan kepada calon responden mengenai hipertensi, terapi relaksasi otot progresif dengan teknik relaksasi nafas dalam, tujuan dan etika dalam penelitian serta menjamin kerahasiaan responden.

e. Jika calon responden bersediah menjadi responden,maka mereka harus menandatangani surat persetujuan menjadi responden yang diberikan peneliti.

f. Peneliti melakukan pengukuran tekanan darah responden sebelum terapi relaksasi otot progresif dengan teknik relaksasi nafas dalam.

g. Selanjutnya responden diberikan terapi relaksasi otot progresif dan teknik relaksasi nafas dalam.

h. Kemudian dilakukan follow up yakni tekanan darah responden diukur 1 jam setelah terapi relaksasi otot progresif dengan teknik relaksasi nafas dalam, kemudian dilakukan evaluasi dan menyampaikan hasil penelitian berupa ada tidaknya penurunan tekanan darah pada responden, serta responden diingatkan kembali untuk tetap melakukan terapi relaksasi otot progresif dengan teknik relaksasi nafas dalam sampai tekanan darah stabil.

i. Mengolah data hasil penelitian.

j. Seminar hasil penelitian.

\section{Variabel Penelitian}

Variabel penelitian yang akan diteliti pada penelitian ini adalah :

a. Variabel Bebas (variabel independen) yaitu terapi relaksasi otot progresif dengan teknik relaksasi nafas dalam.

b. Variabel Terikat (Variabel dependen) yaitu hipertensi

\section{B. Lokasi dan Waktu Penelitian}

Penelitian ini dilaksanakan di

Desa Pulau Birandang Wilayah

Kerja Puskesmas Kampar Timur pada tanggal 19 s/d 26 Juli tahun 2017.

\section{Populasi dan Sampel}

1. Populasi

Populasi dalam penelitian adalah subjek yang memenuhi kriteria yang talah ditetapkan (Nursalam, 2008). Populasi dalam penelitian ini adalah seluruh pasien yang berkunjung ke Puskesmas Kampar timur yang mengalami hipertensi yaitu sebanyak 131 orang.

2. Sampel

Sampel penelitian adalah sebagian dari keseluruhan objek yang diteliti dan dianggap mewakili seluruh populasi (Notoatmojo, 1993, dalam Setiadi, 2007). Pemilihan sampel pada penelitian ini akan dilakukan dengan cara purposive sampling yaitu suatu teknik penetapan sampel dengan cara memilih sampel diantara populasi sesuai dengan kriteria penelitian (Nursalam, 2008). kriteria pemilihan terdiri dari kriteria inklusi dan kriteria ekslusi. Kriteria inklusi adalah karakteristik umum subjek penelitian dari suatu populasi target yang terjangkau dan akan diteliti. Sedangkan kriteria ekslusi adalah menghilang atau menghilangkan subjek yang memenuhi kriteria inklusi dari studi karena berbagai sebab (Nursalam, 2008).

Teknik pengambilan sampel ini berdasarkan pertimbangan tempat, biaya, dan waktu (Burn \& Grove, 2005). Dalam penelitian ini peneliti menetapkan 30 sampel. 
Dalam pengambilan sampel penelitian ini, peneliti menentukan beberapa kriteria inklusi dan eksklusi yaitu:

a. Kriteria Inklusi

1) Bertempat tinggal di Wilayah Kerja Puskesmas Kampar Kabupaten Kampar Timur.

2) Responden yang menderita hipertensi dengan tekanan sistolik 140-159 $\mathrm{mmHg}$, tekanan sistolik 90-99 $\mathrm{mmHg}$.

3) Tidak mengkonsumsi obatobatan hipertensi (obat kimia) dan tidak konsumsi obat-obat tradisional selama dilakukan penelitian.

4) Responden harus mengikuti aturan dari peneliti, seperti:
a) Mengkonsumsi garam tidak lebih dari 30 gram/hari
b) Tidak mengkonsumsi daging kambing dan jeroan
c) Tidak mengkonsumsi makanan instan dan makanan kaleng, seperti kornet, margarain, dan lain - lain
d) Tidak merokok
e) Tidak meminum alkohol
5) Bersedia untuk dijadikan responden penelitian

b. Kriteria ekslusi
1) Pasien hipertensi dengan penyakit komplikasi
2) Menggunakan terapi farmakologis selama dilakukan penelitian

\section{Etika Penelitian}

Masalah etika penelitian
keperawatan merupakan masalah
yang sangat penting dalam
penelitian, mengingat penelitian

keperawatan berhubungan langsung dengan manusia, maka segi etika penelitian harus diperhatikan (Hidayat, 2014). Masalah etika yang harus diperhatikan antara lain sebagai berikut:

\section{Informed Consent}

Lembar persetujuan diberikan kepada subjek yang diteliti. Penelitian menjelaskan maksud dan tujuan penelitian yang dilakukan serta manfaaat yang diperoleh. Setelah responden bersedia, responden harus menandatangani lembar persetujuan menjadi responden. Namun untuk responden yang menolak, peneliti tidak memaksa dan tetap menghormati responden.

2. Tanpa nama (Anonimity)

Untuk menjaga kerahasiaan responden, peneliti tidak mencantumkan nama responden pada lembar pengumpulan data, tetapi cukup dengan member kode pada masing-masing lembar.

3. Kerahasiaan (Confidentiality)

Peneliti menjamin kerahasiaan informasi yang diberikan oleh responden. Hanya kelompok data tertentu yang akan dilaporkan pada hasil penelitian ini.

4. Keadilan (Justice)

Setiap responden mendapatkan perlakuan yang sama dari peneliti yaitu sama-sama mendapatkan penjelasan mengenai penggunaan terapi relaksasi otot progresif dengan teknik relaksasi nafas dalam.

\section{E. Alat Pengumpulan Data}

Alat untuk melakukan pengumpulan data tentang tekanan darah pada penelitian ini dengan menggunakan lembar observasi yang berisikan biodata responden, Sphygmomanometer, dan stetoskop. 
Metode yang digunakan dalam mengetahui penurunan tekanan darah sebelum dan sesudah tindakan dilakukan dengan cara mengukur tekanan darah.

\section{F. Prosedur Pengumpulan Data}

Pengumpulan data yang dilakukan ditempat penelitian menggunakan prosedur sebagai berikut:

1. Tahap Persiapan

Pada saat persiapan penelitian ini, peneliti terlebih dahulu menentukan masalah penelitian, kemudian dilanjutkan dengan mencari studi kepustakaan dan studi pendahuluan. Selanjutnya peneliti menyusun proposal untuk mendapatkan persetujuan pembimbing dan izin penelitian dari pihak Universitas Pahlawan Tuanku Tambusai. Peneliti juga mengurus permohonan izin untuk melakukan penelitian di Wilayah kerja Puskesmas Kampar Timur.

2. Tahap Pelaksanaan
Tahap pelaksanaan ini dimulai setelah peneliti selesai mengurus surat permohonan izin untuk melakukan penelitian di Desa Pulau Birandang Wilayah Kerja Puskesmas Kampar Timur. Peneliti kemudian mendatangi lokasi penelitian yaitu di Desa Pulau Birandang Wilayah Kerja Puskesmas Kampar Timur. Setelah sampai dilokasi penelitian, peneliti melakukan pengecekan kriteria inklusi pada pasien yang mengalami hipertensi. Peneliti menjelaskan maksud penelitian kepada responden yang bersedia. Setelah itu peneliti mengukur tekanan darah pasien dan meminta pasien menandatangani surat persetujuan tindakan (Informed Consent). Peneliti menentukan responden sebanyak 30 orang. Setelah itu barulah peneliti melakukan proses pengumpulan data yang terdiri dari pretest dan posttest.

\section{G. Defenisi Operasional}

Tabel 3.1 Defenisi Operasional

\begin{tabular}{|c|c|c|c|c|}
\hline Variabel & $\begin{array}{c}\text { Defenisi } \\
\text { Operasional }\end{array}$ & $\begin{array}{l}\text { Alat } \\
\text { Ukur }\end{array}$ & Skala Ukur & Hasil ukur \\
\hline $\begin{array}{l}\text { Variabel } \\
\text { Independen } \\
\text { Pemberian } \\
\text { Terapi Relaksasi } \\
\text { Otot Progresif }\end{array}$ & $\begin{array}{l}\text { Pemberian gerakan } \\
\text { pada otot, dahi, mata, } \\
\text { rahang, mulut, leher } \\
\begin{array}{l}\text { belakang dan leher } \\
\text { depan, } \\
\text { mengurangi } \\
\text { ketegangan untuk } \\
\text { kecemasan setiap hari }\end{array}\end{array}$ & $\begin{array}{l}\text { 1.Lembar } \\
\text { observasi }\end{array}$ & Nominal & $\begin{array}{l}\text { 1. Efektif jika terjadi } \\
\text { penurunan tekanan } \\
\text { darah dari sistolik 140- } \\
159 \mathrm{mmHg} \text { dan diastolik } \\
90-99 \mathrm{mmHg} \text { sesudah } \\
\text { pemberian terapi otot } \\
\text { progresif dan tehnik } \\
\text { relaksasi nafas dalam }\end{array}$ \\
\hline $\begin{array}{l}\text { Teknik Relaksasi } \\
\text { Nafas Dalam }\end{array}$ & $\begin{array}{lr}\text { Pemberian } & \text { cara } \\
\text { bernafas } & \text { menarik } \\
\text { nafas dalam } & \text { secara } \\
\text { pelan-pelan } & \text { melalui } \\
\text { hidung } & \text { masuk } \\
\text { kedalam } & \text { perut } \\
\text { kemudian } & \\
\text { dihembuskan } & \text { melalui } \\
\text { mulut setiap hari }\end{array}$ & & & $\begin{array}{l}\text { 2.Tidak efektif jika tidak } \\
\text { terjadi penurunan } \\
\text { tekanan darah dari } \\
\text { sistolik } 140-159 \mathrm{mmHg} \\
\text { dan diastolik } 90-99 \\
\text { mmHg sesudah } \\
\text { pemberian terapi otot } \\
\text { progresif dan tehnik } \\
\text { relaksasi nafas dalam. }\end{array}$ \\
\hline
\end{tabular}




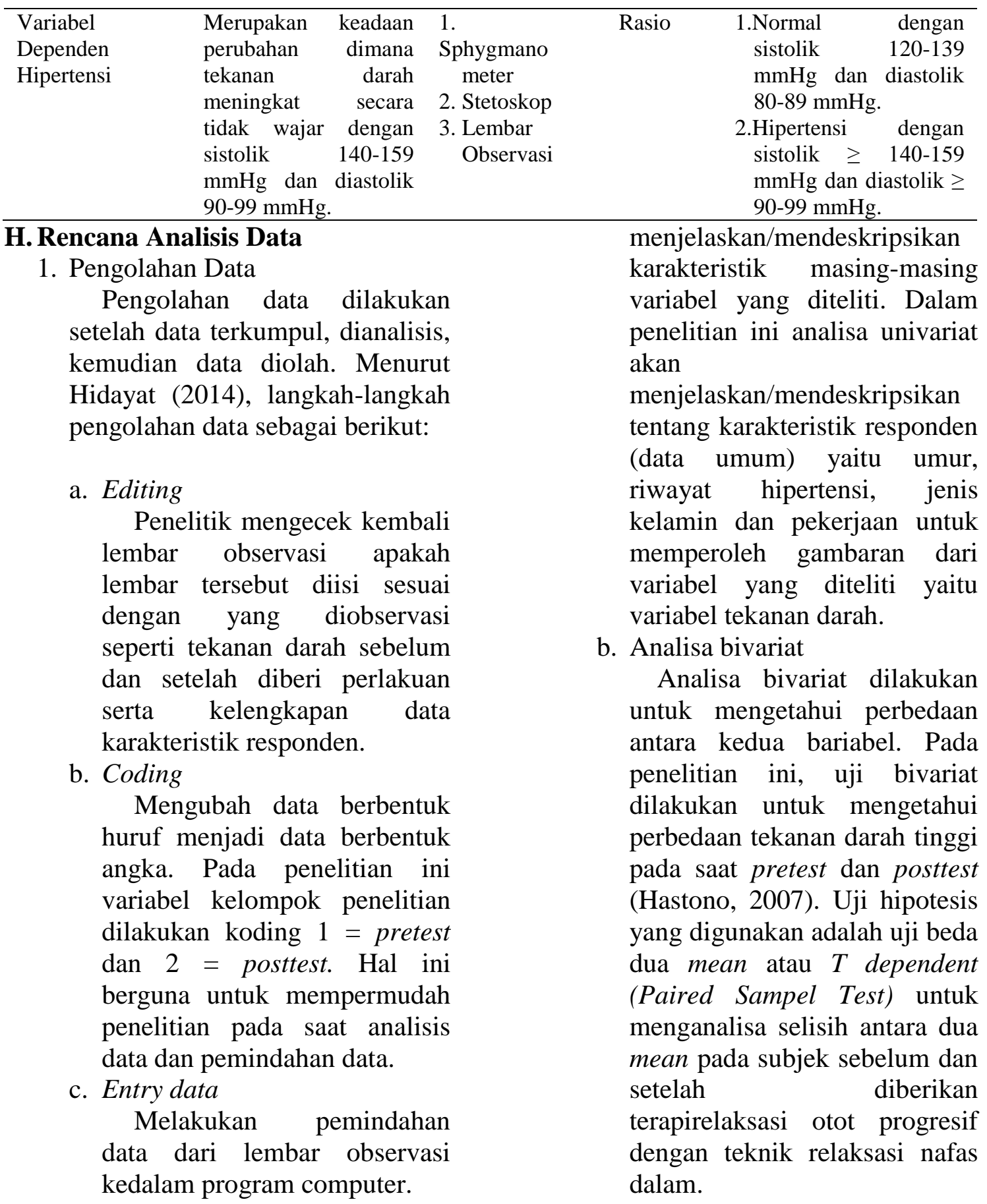

d. Cleaning data

Mengecek kembali apakah ada kesalahan data, sehingga data siap untuk dianalisa.

2. Analisa data

a. Analisa univariat

Menurut Hastono (2007), tujuan dari analisis univariat adalah untuk

\section{BAB IV \\ HASIL PENELITIAN}

Penelitian ini membahas tentang "Efektifitas antara Terapi Relaksasi Otot Progresif dan Teknik Relaksasi Nafas Dalam terhadap Penurunan Tekanan Darah pada Penderita Hipertensi di Desa Pulau Birandang 
Wilayah Kerja Puskesmas Kampar Timur Tahun 2017". Penelitian ini dilaksanakan di Desa Pulau Birandang Wilayah Kerja Puskesmas Kampar Timur pada tanggal 19-26 Juli 2017 di dapat jumlah 30 responden yang memenuhi kriteria inklusi.

Dari 30 orang responden, 15 orang merupakan kelompok intervensi I yaitu kelompok yang diberikan terapi relaksasi otot progresif dan 15 orang sebagai kelompok intervensi II yaitu kelompok yang diberikan teknik relaksasi nafas dalam. Kedua kelompok dilakukan pretest dan posttest kemudian hasilnya di bandingkan. Analisa statistik

Tabel 4.1 Distribusi Frekuensi Tekanan Darah Sistolik Sebelum Pemberian Terapi Relaksasi Otot Progresif dan Teknik Relaksasi Nafas Dalam di Desa Pulau Birandang Wilayah Kerja Puskesmas Kampar Timur Tahun 2017

\begin{tabular}{|c|c|c|c|c|}
\hline Variabel & $\mathbf{N}$ & Mean & SD & Min-Max \\
\hline $\begin{array}{l}\text { Tekanan darah sistolik } \quad \text { sebelum } \\
\text { pemberian Terapi relaksasi otot progresif }\end{array}$ & 15 & 147.33 & 8.837 & $140-160$ \\
\hline $\begin{array}{l}\text { Tekanan darah sistolik sebelum } \\
\text { pemberian Teknik Relaksasi Nafas Dalam }\end{array}$ & 15 & 145.33 & 8.338 & $140-160$ \\
\hline
\end{tabular}

Berdasarkan tabel 4.1 hasil penelitian diperoleh bahwa rata-rata tekanan darah sistolik sebelum pemberian terapi relaksasi otot progresif adalah $147,33 \mathrm{mmHg}$ dengan tekanan darah sistolik terendah 140 dan tertinggi 160 .

Tabel 4.2 Distribusi Frekuensi Tekanan Darah Diastolik Sebelum Pemberian Terapi Relaksasi Otot Progresif dan Teknik Relaksasi Nafas Dalam di Desa Pulau Birandang Wilayah Kerja Puskesmas Kampar Timur Tahun 2017

\begin{tabular}{lccccc}
\hline \multicolumn{2}{c}{ Variabel } & N & Mean & SD & Min-Max \\
\hline $\begin{array}{l}\text { Tekanan darah diastolik sebelum } \\
\text { pemberian Terapi relaksasi otot progresif }\end{array}$ & 15 & 84.67 & 7.432 & $70-90$ \\
\hline $\begin{array}{l}\text { Tekanan darah diastolik sebelum } \\
\text { pemberian Teknik Relaksasi Nafas Dalam }\end{array}$ & 15 & 90.00 & 6.546 & $80-100$ \\
\hline
\end{tabular}

\section{Sumber: Hasil Penelitian}

Berdasarkan tabel 4.2 hasil penelitian diperoleh bahwa rata-rata tekanan darah diastolik sebelum pemberian terapi relaksasi otot progresif adalah 84,67 $\mathrm{mmHg}$ dengan tekanan darah diastolik terendah $70 \mathrm{mmHg}$ dan tertinggi 90 data hasil penelitian di tampilkan sebagai berikut:

\section{A. Analisis Univariat}

Analisis Univariat dilakukan terhadap tiap variabel dari hasil penelitian. Dalam penelitian ini penelitian menganalisa data secara univariat untuk melihat distribusi karakteristik responden, tekanan darah sebelum dan sesudah pemberian terapi relaksasi otot progresif dan teknik relaksasi nafas dalam.

Sedangkan tekanan darah sistolik rata-rata sebelum diberikan relaksasi nafas dalam adalah $145,33 \mathrm{mmHg}$ dengan tekanan darah sistolik terendah $140 \mathrm{mmHg}$ dan tertinggi $160 \mathrm{mmHg}$.

mmHg. Sedangkan tekanan darah diastolik rata-rata sebelum diberikan relaksasi nafas dalam adalah 90,00 mmHg dengan tekanan darah diastolik terendah $80 \mathrm{mmHg}$ dan tertinggi $100 \mathrm{mmHg}$. 
Tabel 4.3 Distribusi Frekuensi Tekanan Darah Sistolik Sesudah Pemberian Terapi Relaksasi Otot Progresif dan Teknik Relaksasi Nafas Dalam di Desa Pulau Birandang Wilayah Kerja Puskesmas Kampar Timur Tahun 2017

\begin{tabular}{lccccc}
\hline \multicolumn{1}{c}{ Variabel } & N & Mean & SD & Min-Max \\
\hline $\begin{array}{l}\text { Tekanan darah sistolik sesudah } \\
\text { pemberian Terapi relaksasi otot progresif }\end{array}$ & 15 & 128.00 & 8.619 & $120-150$ \\
\hline $\begin{array}{l}\text { Tekanan darah sistolik sesudah } \\
\text { pemberian Teknik Relaksasi Nafas Dalam }\end{array}$ & 15 & 131.33 & 9.155 & $120-160$ \\
\hline
\end{tabular}

Sumber: Hasil Penelitian

Berdasarkan tabel 4.3 hasil penelitian diperoleh bahwa rata-rata tekanan darah sistolik sesudah pemberian terapi relaksasi otot progresif adalah 128,00 $\mathrm{mmHg}$ dengan tekanan darah sistolik terendah $120 \mathrm{mmHg}$ dan tertinggi
150 mmHg. Sedangkan tekanan darah sistolik rata-rata sesudah diberikan relaksasi nafas dalam adalah 131,33 $\mathrm{mmHg}$ dengan tekanan darah sistolik terendah 120 $\mathrm{mmHg}$ dan tertinggi $160 \mathrm{mmHg}$.

Tabel 4.4 Distribusi Frekuensi Tekanan Darah Diastolik Sesudah Pemberian Terapi Relaksasi Otot Progresif dan Teknik Relaksasi Nafas Dalam di Desa Pulau Birandang Wilayah Kerja Puskesmas Kampar Timur Tahun 2017

\begin{tabular}{lcccccc}
\hline \multicolumn{2}{c}{ Variabel } & N & Mean & SD & Min-Max \\
\hline $\begin{array}{l}\text { Tekanan darah diastolik sesudah } \\
\text { pemberian Terapi relaksasi otot progresif }\end{array}$ & 15 & 79.33 & 4.577 & $70-90$ \\
\hline $\begin{array}{l}\text { Tekanan darah diastolik sesudah } \\
\text { pemberian Teknik Relaksasi Nafas Dalam }\end{array}$ & 15 & 81.33 & 5.163 & $80-100$ \\
\hline
\end{tabular}

\section{Sumber: Hasil Penelitian}

Berdasarkan tabel 4.4 hasil penelitian diperoleh bahwa rata-rata tekanan darah diastolik sesudah pemberian terapi relaksasi otot progresif adalah $79,33 \mathrm{mmHg}$ dengan tekanan darah diastolik terendah $70 \mathrm{mmHg}$ dan tertinggi 90 mmHg. Sedangkan tekanan darah diastolik rata-rata sesudah diberikan relaksasi nafas dalam adalah 81,33 $\mathrm{mmHg}$ dengan tekanan darah diastolik terendah $80 \mathrm{mmHg}$ dan tertinggi $100 \mathrm{mmHg}$.

Tabel 4.5 Distribusi Perbedaan Rata-Rata Sistolik Sebelum dan Sesudah Pemberian Tehnik Relaksasi Otot Progresif di Desa Pulau Birandang Wilayah Kerja Puskesmas Kampar Timur Tahun 2017

\begin{tabular}{|c|c|c|c|c|c|}
\hline Variabel & $\mathbf{N}$ & Mean & SD & SE & $\begin{array}{c}\mathbf{P} \\
\text { Value }\end{array}$ \\
\hline $\begin{array}{l}\text { Tekanan darah sistolik sebelum pemberian } \\
\text { Terapi relaksasi otot progresif }\end{array}$ & 15 & 147.33 & 8.837 & 2.282 & \multirow{2}{*}{0.000} \\
\hline $\begin{array}{l}\text { Tekanan darah sistolik sesudah pemberian } \\
\text { Terapi relaksasi otot progresif }\end{array}$ & 15 & 128.00 & 8.619 & 2.225 & \\
\hline
\end{tabular}

\section{B. Analisis Bivariat}

Analisa bivariat dilakukan untuk melihat perbandingan penurunan tekanan darah sebelum dan sesudah di berikan terapi relaksasi otot progresif. Perbedaan rata-rata penurunan tekanan darah sebelum dan sesudah diberikan terapi relaksasi otot progresif dan tehnik relaksasi nafas dalam peneliti sajikam dalam bentuk tabel sebagai berikut:

Sumber: Hasil Penelitian 
Berdasarkan tabel 4.5 terlihat bahwa perbandingan efektifitas antara sebelum pemberian terapi relaksasi otot progresif adalah 147,33 $\mathrm{mmHg}$ dengan standar deviasi sebesar 8,837 dan sesudah pemberian terapi otot progresif adalah 128,00 $\mathrm{mmHg}$ dengan standar deviasi 8.619 dan nilai rata-rata penurunannya sebesar 19,33 mmHg. Hasil uji statistik didapatkan nilai $\mathrm{p}$ value $0,000(\leq 0,05)$ yang artinya terdapat efektifitas pemberian terapi relaksasi otot progresif terhadap penurunan tekanan darah sistolik pada penderita Hipertensi di Desa Pulau Birandang Wilayah Kerja Puskesmas Kampar timur Tahun 2017.

Tabel 4.6 Distribusi Perbedaan Rata-Rata Sistolik Sebelum dan Sesudah Pemberian Tehnik Relaksasi Nafas Dalam di Desa Pulau Birandang Wilayah Kerja Puskesmas Kampar Timur Tahun 2017

\begin{tabular}{|c|c|c|c|c|c|}
\hline Variabel & $\mathbf{N}$ & Mean & SD & SE & $\begin{array}{c}\mathbf{P} \\
\text { Value }\end{array}$ \\
\hline $\begin{array}{l}\text { Tekanan darah sistolik sebelum } \\
\text { pemberian Tehnik relaksasi nafas dalam }\end{array}$ & 15 & 145.33 & 8.338 & 2.153 & \multirow{2}{*}{0.000} \\
\hline $\begin{array}{l}\text { Tekanan darah sistolik } \\
\text { pemberian Tehnik relaksasi nafas dalam }\end{array}$ & 15 & 131.33 & 9.155 & 2.364 & \\
\hline
\end{tabular}

\section{Sumber: Hasil Penelitian}

Berdasarkan tabel 4.6 terlihat bahwa perbandingan efektifitas antara sebelum pemberian tehnik relaksasi nafas dalam adalah 145,33 $\mathrm{mmHg}$ dengan standar deviasi sebesar 8,558 dan sesudah pemberian tehnik relaksasi nafas dalam adalah $131,33 \mathrm{mmHg}$ dengan standar deviasi 9,155 dan nilai rata-rata

\section{Tabel 4 Distribusi Perbedaan Rata-Rata} Terapi Relaksasi Otot Progresif di Desa Pulau Birandang Wilayah Kerja Puskesmas Kampar Timur Tahun 2017

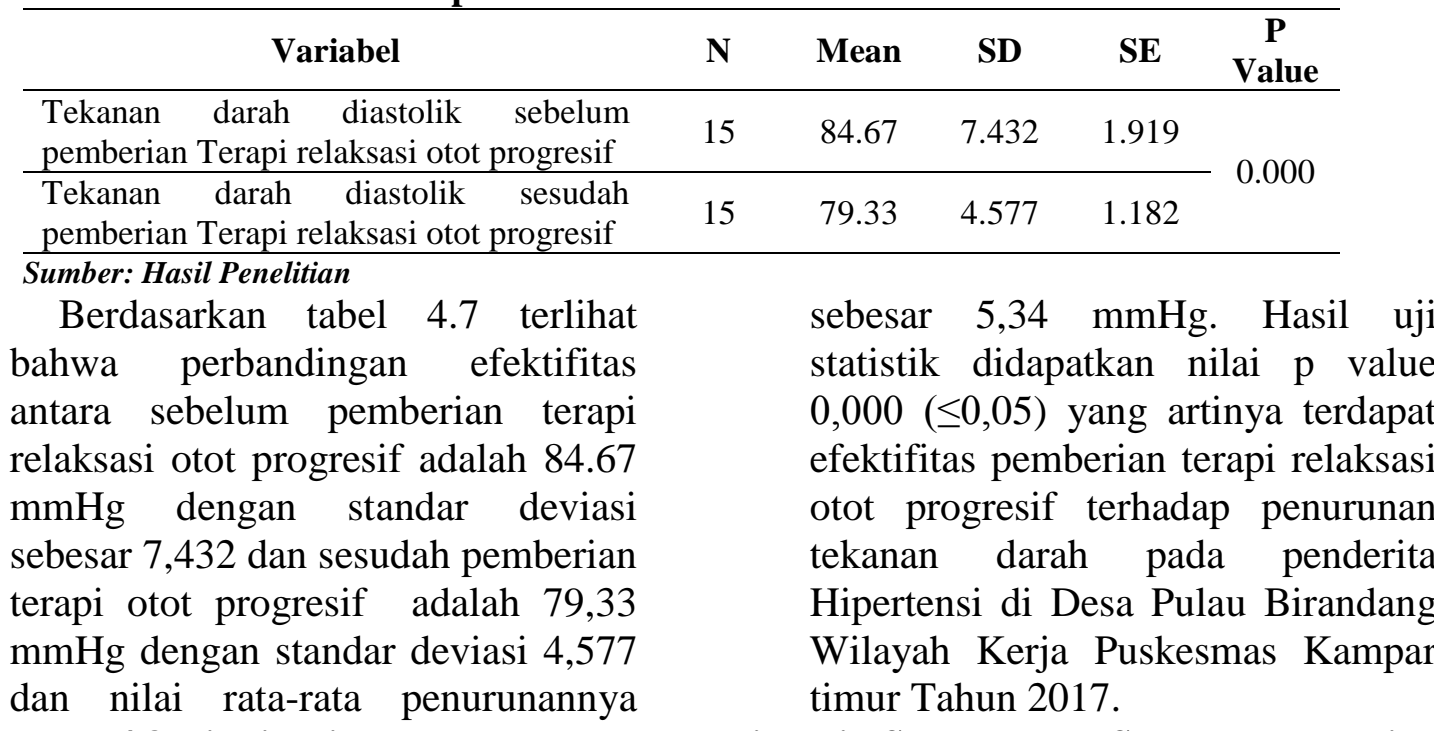

Tabel 4.8 Distribusi Perbedaan Rata-Rata Diastolik Sebelum dan Sesudah Pemberian Tehnik Relaksasi Nafas Dalam di Desa Pulau Birandang Wilayah Kerja Puskesmas Kampar Timur Tahun 2017 Hasil uji statistik didapatkan nilai $\mathrm{p}$ value $0,000(\leq 0,05)$ yang artinya terdapat efektifitas pemberian tehnik relaksasi nafas dalam terhadap penurunan tekanan darah pada penderita Hipertensi di Desa Pulau Birandang Wilayah Kerja Puskesmas Kampar timur Tahun 2017.

Rata Diastolik Sebelum dan Sesudah Pemberian$$
\text { Puskesmas Kampar Timur Tahun } 2017
$$ 


\begin{tabular}{|c|c|c|c|c|c|}
\hline Variabel & $\mathbf{N}$ & Mean & SD & SE & $\begin{array}{c}\mathbf{P} \\
\text { Value }\end{array}$ \\
\hline $\begin{array}{l}\text { Tekanan darah diastolik } \text { sebelum } \\
\text { pemberian Tehnik relaksasi nafas dalam }\end{array}$ & 15 & 90.00 & 6.546 & 1.690 & \multirow{2}{*}{0.000} \\
\hline $\begin{array}{l}\text { Tekanan darah diastolik sesudah } \\
\text { pemberian Tehnik relaksasi nafas dalam }\end{array}$ & 15 & 81.333 & 5.163 & 1.333 & \\
\hline
\end{tabular}

Sumber: Hasil Penelitian

Berdasarkan tabel 4.8 terlihat bahwa perbandingan efektifitas antara sebelum pemberian tehnik relaksasi nafas dalam adalah 90,00 $\mathrm{mmHg}$ dengan standar deviasi sebesar 6,546 dan sesudah pemberian tehnik relaksasi nafas dalam adalah $81.333 \mathrm{mmHg}$ dengan standar deviasi 5,163 dan nilai ratarata penurunannya sebesar 8,67 mmHg. Hasil uji statistik didapatkan nilai $\mathrm{p}$ value $0,000 \quad(\leq 0,05)$ yang artinya terdapat efektifitas pemberian tehnik relaksasi nafas dalam terhadap

Tabel 4.9 Distribusi Perbedaan Rata-Rata antara Terapi Relaksasi Otot Progresif dan Tehnik Nafas Dalam Terhadap Penurunan Tekanan Darah di Desa Pulau Birandang Wilayah Kerja Puskesmas Kampar Timur Tahun 2017

\begin{tabular}{|c|c|c|c|c|c|c|}
\hline Variabel & $\mathbf{N}$ & $\begin{array}{c}\text { Mean } \\
\text { sistolik }\end{array}$ & $\begin{array}{c}\text { Mean } \\
\text { Diastolik }\end{array}$ & SD & $\begin{array}{l}\text { SE Sistolik } \\
\text { dan } \\
\text { diastolik }\end{array}$ & $\begin{array}{c}\mathbf{P} \\
\text { value }\end{array}$ \\
\hline $\begin{array}{l}\text { Tekanan darah pemberian } \\
\text { Tehnik relaksasi otot } \\
\text { progresif }\end{array}$ & 15 & 128.00 & 79.33 & 8.619 & $\begin{array}{l}2.225 \\
1.182\end{array}$ & \multirow{2}{*}{0.000} \\
\hline $\begin{array}{l}\text { Tekanan darah pemberian } \\
\text { Tehnik relaksasi nafas } \\
\text { dalam }\end{array}$ & 15 & 131.33 & 81.33 & 4.577 & $\begin{array}{l}2.364 \\
1.333\end{array}$ & \\
\hline
\end{tabular}

Berdasarkan tabel 4.9 diatas, diperoleh hasil penelitian dengan nilai rata-rata penurunan tekanan darah hipertensi pada responden yang diberikan terapi relaksasi otot progresif sistolik menjadi 128,00 mmHg dan diastol menjadi 79,33 $\mathrm{mmHg}$ dan nilai rata-rata penurunan tekanan darah hipertensi pada responden yang diberikan tehnik relaksasi nafas dalam sistolik menjadi $131,33 \mathrm{mmHg}$ dan diastolik menjadi 81,33 mmHg.Sedangkan untuk nilai $\mathrm{p}=$ value $0.000<\mathrm{a}=0,05$ ) yang artinya terdapat perbedaan yang signifikan antara terapi relaksasi otot penurunan tekanan darah pada penderita Hipertensi di Desa Pulau Birandang Wilayah Kerja Puskesmas Kampar timur Tahun 2017. progresif dan tehnik relaksasi nafas dalam terhadap penurunan tekanan darah pada penderita hipertensi, dimana penurunan tekanan darah pada tehnik relaksasi otot progresif lebih efektif daripada pemberian tehnik nafas dalam.

\section{BAB V \\ PEMBAHASAN}

Penelitian ini membahas tentang "Efektifitas Antara Terapi Relaksasi Otot Progresif dan Tehnik Relaksasi Nafas Dalam Terhadap Penurunan Tekanan Darah Pada Penderita Hipertensi di Desa Pulau Birandang 
Wilayah Kerja Puskesmas Kampar Timur Tahun 2017 ".

\section{A. Pembahasan Penelitian}

\section{Efektifitas Terapi Relaksasi Otot Progresif Terhadap Penurunan Tekanan Darah Penderita Hipertensi}

Berdasarkan hasil penelitian pada tabel 4.5 didapatkan bahwa hasil analisis data tentang penurunan tekanan darah sistolik antara sebelum dan sesudah diberikan terapi relaksasi otot progresif, bahwa perbedaan sebelum melakukan tehnik relaksasi otot progresif adalah 147,33 $\mathrm{mmHg}$ dan sesudah pemberian terapi otot progresif adalah $128,00 \mathrm{mmHg}$ dan nilai rata-rata penurunannya sebesar 19,33 $\mathrm{mmHg}$ dan berdasarkan tabel 4.7 didapatkan bahwa hasil analisis data tentang penurunan tekanan darah diastolik antara sebelum dan sesudah diberikan terapi relaksasi otot progresif, bahwa perbedaan sebelum pemberian terapi relaksasi otot progresif adalah $84,67 \mathrm{mmHg}$ dan sesudah pemberian terapi otot progresif adalah 79,33 $\mathrm{mmHg}$ dan nilai rata-rata penurunannya sebesar 5,34 mmHg. Hasil uji statistik didapatkan nilai $\mathrm{p}$ value $0,001 \quad(\leq 0,05)$, maka dapat disimpulkan ada perbedaan signifikan rata-rata antara tekanan darah sistolik dan diastolik sebelum dan sesudah pemberian tehnik relaksasi otot progresif.

Menurut asumsi peneliti, terdapat efektifitas tehnik relaksasi otot progresif terhadap perubahan tekanan darah sistolik dan diastolik pada penderita hipertensi, perbedaan penurunan tekanan darah sistolik dan diastolik pada responden yang diberikan intervensi tehnik relaksasi otot progresif dan responden yang diberikan intervensi tehnik relaksasi nafas dalam terjadi karena perbedaan cara kerja masing-masing intervensi dalam memberikan perlakuan. Perbedaan yang terjadi karena $\mathrm{ACTH}$ (adrenocorticotropic hormone) dan CRH (cotricotropin releasing hormone) di kelenjar hypothalamus menurun. Penurunan kedua sekresi hormon ini menyebabkan aktivitas syaraf simpatis menurun sehingga pengeluaran hormon adrenalin dan noradrenalin berkurang, akibatnya terjadi penurunan denyut jantunvb, pembuluh darah melebar, tahanan pembuluh darah berkurangdan penuruanan pompa jantung sehingga tekanan darah arteria jantung menurun.

Penelitian yang dilakukan oleh Shinde, KJ, SM dan Hande (2013) tentang "Efektifitas Relaksi Otot Progresif Terhadap Tekanan Darah Pada Penderita Hipertensi Esensial" Hasil penelitian menunjukan terdapat perbedaan yang segnifikan pada tekanan darah dan jantung pre dan post intervensi, secara stastistik didapatkan hasil pada tekanan darah sistolik $(\mathrm{p}<0,01)$. Tekanan darah diastolic $(\mathrm{p}=0,05)$ dan denyut jantung $(\mathrm{p}<0,05)$ terjadi penurunan yang segnifikan setelah melaksanakan relaksasi otot progresif.

2. Efektifitas Tehnik Relaksasi Nafas Dalam Terhadap Penurunan Tekanan Darah Penderita Hipertensi 
Berdasarkan hasil penelitian tabel 4.6 diperoleh bahwa hasil analisa data tentang perbedaan tekanan darah sistolik antara sebelum dan sesudah pemberian tehnik relaksasi nafas dalam,bahwa perbedaan sebelum pemberian tehnik relaksasi nafas dalam adalah 145,33 $\mathrm{mmHg}$ dan sesudah pemberian tehnik relaksasi nafas dalam adalah 131,33 mmHg 9,155 dan nilai rata-rata penurunannya sebesar 14 mmHg. Hasil uji statistik didapatkan nilai $\mathrm{p}$ value 0,000 $(\leq 0,05)$ dan Berdasarkan tabel 4.8 terlihat bahwa hasil analisa data tentang perbedaan antara sebelum pemberian tehnik relasasi nafas dalam adalah 90,00 $\mathrm{mmHg}$ dan sesudah pemberian tehnik relaksasi nafas dalam adalah $81,333 \mathrm{mmHg}$ dan nilai rata-rata penurunannya sebesar 8,67 mmHg. Hasil uji statistik didapatkan nilai $\mathrm{p}$ value 0.000 $(\leq 0,05)$, maka dapat disimpulkan ada perbedaan signifikan rata-rata antara tekanan darah sistolik dan diastolik sebelum dan sesudah pemberian tehnik relaksasi nafas dalam.

Menurut asumsi peneliti, terdapat efektifitas tehnik relaksasi nafas dalam terhadap penurunan tekanan darah sistolik dan diastolik pada penderita hipertensi. Tehnik relaksasi nafas dalam meningkatkan ventilasi alveoli, memelihara pertukaran gas, mencegah atelektasi paru, meningkatkan efisiensi bentuk mengurangi stress baik stress fisik maupun emosional yaitu menurunkan intensitas nyeri dan menurunkan kecemasan.
Penelitian ini juga sesuai dengan penelitian yang dilakukan oleh Rini Tri Hastuti, Insiyah dengan judul "Penurunan Tekanan Darah Dengan Menggunakan Teknik Nafas Dalam (DEEP BREATHING) Pada Pasien Hipertensi Di Puskesmas Bendosari Kabupaten Sukoharjo Tahun 2015" Hasil peneitian ini menunjukkan bahwa tekanan darah pada pasien hipertensi di Puskesmas Bendosari Kabupaten Sukoharjo sebelum terapi teknik terapi nafas dalam (DEEP BREATHING) yaitu tekanan darah sistol rata-rata $177,33 \mathrm{mmhg}$ dan diastol rata-rata 95,87 mmhg. Tekanan darah pada pasien hipertensi di Puskesmas Bendosari Kabupaten Sukoharjo sesudah terapi teknik nafas dalam (DEEP BREATHING) yaitu tekanan darah sistol rata-rata 173,20 mmhg dan diastol rata-rata $90,57 \mathrm{mmhg}$. Ada pengaruh terapi teknik nafas dalam terhadap penurunan tekanan darah pada pasien hipertensi di Puskesmas Bendosari Kabupaten Sukoharjo.

3. Perbedaan Efektifitas Terapi Relaksasi Otot Progresif dan Tehnik Relaksasi Otot Progresif Terhadap Penurunan Tekanan Darah Penderita Hipertensi

Berdasarkan hasil penelitian pada tabel 4.9 yang dilakukan dengan uji T-Dependent untuk membandingkan antara terapi relaksasi otot progresif dan tehnik relaksasi nafas dalamterhadap penurunan tekanan darah pada penderita hipertensi, bahwa perbedaan sebelum diberikan terapi relaksasi otot progresif adalah sistolik 147.33 dan diastolik 84,67 $\mathrm{mmHg}$ dengan 
sesudah menjadi $128,00 \mathrm{mmHg}$ dan diastole menjadi 79,33 $\mathrm{mmHg}$ dan nilai rata-rata penurunan tekanan darah sistolik 19,33 $\mathrm{mmHg}$ dan diastolik 5,333 mmHg, sedangkan pada responden yang sebelum diberikan tehnik relaksasi nafas dalam sistolik 145,33 $\mathrm{mmHg}$ dan diastolik 90,00 dengan sesudah diberikan tehnik relaksasi nafas dalam adalah sistolik 131,33 $\mathrm{mmHg}$ dan diastolik menjadi $81,33 \mathrm{mmHg}$ nilai rata-rata penurunan tekanan darah sistolik $14 \mathrm{mmHg}$ dan diastolik 8,67 mmHg. Hasil uji T-Dependent menujkkan nilai $\mathrm{p}=0,000<$ $\mathrm{a}=0,05$ ) yang artinya terdapat perbedaan yang signifikan antara terapi relaksasi otot progresif dan tehnik relaksasi nafas dalam terhadap penurunan tekanan darah pada penderita hipertensi.

Menurut asumsi peneliti lakukan selama penelitian, perbedaan penurunan tekanan darah pada responden yang diberikan intervensi terapi relaksasi otot progresif dan responden yang diberikan intervensi tehnik relaksasi nafas dalam terjadi karena cara kerja masing-masing intervensi dalam memberikan perlakuan.

Perbedaan yang terjadi karena ACTH (adrenocorticotropic hormone) dan CRH (cotricotropin releasing hormone) di kelenjar hypothalamus menurun. Penurunan kedua sekresi hormon ini menyebabkan aktivitas syaraf simpatis menurun sehingga pengeluaran hormon adrenalin dan noradrenalin berkurang, akibatnya terjadi penurunan denyut jantung, pembuluh darah melebar, tahanan pembuluh darah berkurang dan penuruanan pompa jantung sehingga tekanan darah arteria jantung menurun. Responden juga mengatakan perubahan yang dirasakan setelah dilakukan intervensi terapi relaksasi otot progresif seperti responden merasakan darahnya mengalir dan badan menjadi lebih segar.

Terapi relaksasi otot progresif dan tehnik relaksasi nafas dalam dapat menurunkan tekanan darah, dari rata-rata penurunan dapat dilihat pada terapi relaksasi otot progresif sistolik $19,33 \mathrm{mmHg}$ dan diastolik 5,34 $\mathrm{mmHg}$ sedangkan penurunan tekanan darah pada responden tehnik relaksasi nafas dalam sistolik 14 $\mathrm{mmHg}$ dan diastolik $8,67 \mathrm{mmHg}$ yang berarti terapi relaksasi otot orogresif lebih efektif dalam menurunkan tekanan darah pada penderita hipertensi.

\section{B. Keterbatasan Penelitian}

Dalam penelitian ini peneliti mengalami keterbatasan penelitian yaitu, kurangnya sumber penelitian terkait dan jarak yang lumayan jauh dari tempat peneliti dan tempat penelitian.

\section{DAFTAR PUSTAKA}

As-sayyid, 2014. Menurunkan Tekanan

Darah. Jakarta : Buana Ilmu Populer

Brook, et al, 2013. Gambaran Tentang Penderita Hipertensi. Diperoleh tanggal 13 April 2012 dari http://addy.wordpress.com

Davis, 1995 dalam Erliana 2008. Pengaruh Teknik Relaksasi 
Terhadap Tekanan Darah. Jurnal Ilmu Kesehatan

Endeh Nurgiwiati, DPN, SKM, MCPN, 2015. Terapi Anternatif dan Komplementer dalam Bidan Keperawatan. Bogor : Media

Izzon, 2008. Pelayanan Keperawatan Bagi Penderita Hipertensi Secara Terpadu. Yogyakarta : Graha Ilmu

Jain, 2011. Rencana Asuhan Keperawatan._Jakarta : EGC

Kholish, 2011. Penuntun Praktis Penyakit Kardiovaskuler. Jakarta :Buku Kedokteran EGC.

Kemenkes RI, 2012. Masih Tingginya Penderita Hipertensi di Asean. Diperoleh tanggal 27 Mai 2010 dari http://www. who. int/ media centre/ factsheets /fs363/en/)

Lemone \& Burke, 2008. Panduan Cerdas Mengatasi Hipertensi. Yogyakarta : Araska

Murti, 2011. Pedoman Klinis Diagnosis dan Terapi. Jakarta: Hipokrates

Mulia Medika, 2014 Standar Perawatan Pasien : Proses Keperawatan, Diagnosis dan Evaluasi. Jakarta : EGC

Noviyanti, S.km, 2015. Hipertensi Kenali, Cegah \& Obati. Yogyakarta : Bukupintar

Purwanto, 2007. Teknik Relaksasi untuk Mengatasi Stress. Diperoleh tanggal 21 Mai 2016 dari http://www.wikimu.com/news/Dis playnews.aspx?id15495

Ratna Dewi Pudiastuti, 2011. Penyakit Pemicu STROKE. Yogyakarta : Nuha Medika

Sherwood, 2011. Asuhan Keperawatan (Marternitas, Anak, Bedah, dan Penyakit Dalam). Yogjakarta : Nuha Medika

Smeltzer \& Bare, 2002. Tekanan Darah Tinggi : Mengapa Terjadi,
Bagaimana mengatasinya. Jakarta: Arcan

Sri Rahmadina, dkk \& Prihanjo, 2003. Menaklukkan Hipertensi Dan Diabetes. Jakarta Selatan : PT. Suka Buku

Tamsuri, 2004, Konsep Dan Proses Keperawatan Nyeri. Yogjakarta : AR-Ruzz Medika

Triyanto. 2014. Pelayanan Keperawatan Bagi Penderita Hipertensi Secara Terpadu. Yogyakarta : Graha Ilmu

Stikes Tuanku Tambusai Riau. 2014. Panduan Penulisan Laporan Tugas Akhir. Riau 